\title{
Pendapatan Asli Daerah, Dana Bagi Hasil Pajak dan Bukan Pajak, Dana Alokasi Umum dan Dana Alokasi Khusus dan Belanja Modal pada Kabupaten/Kota Provinsi Jawa Barat
}

\author{
Wahyu Pamuji ${ }^{1}$, Willy Abdillah ${ }^{2}$ \\ ${ }^{1}$ Universitas Pancasila, Jl. Srengseng Sawah, Jagakarsa, Jakarta Selatan 12640 \\ ${ }^{2}$ Universitas Bengkulu, Jl. W.R Supratman Kandang Limun, Bengkulu 38371
}

\section{N F O A R T I K E L}

\author{
JEL Classification: \\ H83 \\ M12
}

Keywords:

original local government revenue, tax/non tax revenue sharing, general allocation funds, special allocation funds, and capital expenditure.

\section{$A B S T R A C T$}

This study aims to examine the effect of income, revenuesharing, general allocation fund and a special allocation of funds for capital expenditure District / City in West Java province in 2008 - 2012. The analysis method used in this research is quantitative method with regression testing multiple test the classic assumption before it get the best research model. The variables in this study were of income, revenue-sharing, general allocation fund and a special allocation fund as an independent variable and capital expenditures as the dependent variable. These results prove that the local revenue, revenue-sharing, general allocation fund and a special allocation fund a significant effect on of capital expenditure on Kabupaten / Kota in the province of West Java. The results of the study provide evidence that regional income, revenue-sharing, general allocation fund a significant effect on capital expenditure, while the special allocation variables no significant effect on of capital expenditure. This study shows that the potential of the region will determine the composition of of capital expenditure in Kabupaten / Kota in West Java Province.

\begin{abstract}
A B S T R A K
Penelitian ini bertujuan menguji pengaruh pendapatan asli daerah, dana bagi hasil, dana alokasi umum dan dana alokasi khusus terhadap belanja modal Pemerintah Kabupaten/Kota di Provinsi Jawa Barat tahun 2008 - 2012. Metode analisis yang digunakan dalam penelitian ini adalah metode kuantitatif, dengan pengujian regresi berganda dengan melakukan uji asumsi klasik sebelum mendapatkan model penelitian terbaik. Variabel dalam penelitian ini adalah pendapatan asli daerah, dana bagi hasil, dana alokasi umum dan dana alokasi khusus sebagai variabel independen dan Belanja Modal sebagai variabel dependen. Hasil penelitian ini membuktikan bahwa pendapatan asli daerah, dana bagi hasil, dana alokasi umum dan dana alokasi khusus berpengaruh signifikan terhadap belanja modal pada Kabupaten/Kota di Provinsi Jawa Barat. Hasil penelitian memberikan bukti bahwa pendapatan asli daerah, dana bagi hasil, dana alokasi umum
\end{abstract}




\begin{abstract}
berpengaruh signifikan terhadap belanja modal, sedangkan varibel dana alokasi khusus tidak berpengaruh signifikan terhadap belanja modal. Penelitian ini menunjukkan bahwa potensi daerah sangat menentukan komposisi belanja modal pada kabupaten/kota di Provinsi Jawa Barat.
\end{abstract}

\section{Pendahuluan}

Sejak dimulainya otonomi daerah, implementasi kebijakan desentralisasi fiskal telah mengalami perkembangan dari tahun ke tahun (Arifintar, 2013). Perhatian pemerintah pusat kepada pemerintah daerah juga semakin besar, karena pembangunan daerah merupakan bagian integral dan penjabaran pembangunan nasional dalam rangka pencapaian sasaran pembangunan yang disesuaikan dengan potensi, aspirasi dan permasalahan pembangunan di daerah. Kenyataan bahwa potensi, kekayaan dan kemampuan keunangan antar daerah dalam membiayai pembangunan berbedabeda menyebabkan terjadinya disparitas pembangunan antar daerah/wilayah terutama terjadi antara perdesaan dan perkotaan, antara Pulau Jawa dan luar Jawa, antara pusat-pusat pertumbuhan dengan kawasan hinterland dan kawasan perbatasan, serta antara Kawasan Barat Indonesia dengan Kawasan Timur Indonesia. Kesenjangan tingkat pembangunan di daerah dapat ditunjukkan oleh berbagai indikator seperti kondisi infrastruktur transportasi, komunikasi, pendidikan, kesehatan, ekonomi, olah raga dan kesenian dan lain-lain. Kesenjangan terlihat pula dari segi "kualitas" sumber daya manusianya seperti tingkat pendidikan dan ketrampilan, harapan hidup, gizi anak, dan seterusnya seperti yang terangkum dalam Indeks Pembangunan Manusia (IPM). Demikian pula dengan pendapatan per kapita maupun tingkat kemiskinan penduduknya, menunjukkan adanya kesenjangan antar wilayah di republik ini, (Kinseng, 2011).

Salah satu instrumen untuk mengurangi kesenjangan antar daerah adalah kebijakan transfer ke daerah. Kebijakan transfer ke daerah dilaksanakan dengan memperhatikan aspek kesenjangan fiskal antara pusat dan daerah, antar daerah, pembagian urusan pemerintahan antara pusat, provinsi, dan kabupaten/kota, kualitas dan kesenjangan pelayanan publik antar daerah, pengembangan potensi ekonomi daerah, efisiensi pemanfaatan sumber daya nasional, sinkronisasi perencanaan pembangunan nasional dan daerah, percepatan pembangunan di daerah tertingal, terluar, terdepan, dan pasca konflik. Menurut Simanjuntak (dalam Sidik et all, 2002), kebijakan transfer ke daerah bertujuan untuk mengurangi kesenjangan fiskal antar daerah dan menjamin tercapainya standar pelayanan publik minimum (SPM) di seluruh daerah.

Besarnya dana transfer yang digulirkan kepada pemerintah daerah harus diiringi dengan adanya peningkatan pelayanan dan kesejahteraan masyarakat. Peningkatan layanan publik ini diharapkan juga dapat meningkatkan daya tarik bagi investor untuk membuka usaha di daerah. Hal ini dapat terwujud apabila ada upaya pemerintah dengan memberikan berbagai fasilitas untuk investasi. Konsekuensinya, pemerintah perlu memberikan alokasi belanja yang lebih besar untuk tujuan ini. Fenomena yang terjadi sekarang ini adalah adanya kecenderungan bahwa beban belanja rutin pemerintah daerah semakin besar dan pemerintah daerah semakin sulit untuk melakukan pembangunan infrastruktur.

Komponen belanja modal sangat erat kaitannya dengan investasi yang dilakukan oleh pemerintah daerah. Peningkatan alokasi belanja modal dalam bentuk aset tetap seperti pembangunan infrastruktur dan peralatan sangat penting untuk meningkatkan produktivitas perekonomian. Tersedianya sarana/prasarana publik yang memadai akan merangsang transaksi ekonomi lokal. Peningkatan belanja modal terutama untuk proyek-proyek infrastruktur diharapkan dapat mendukung peningkatan pertumbuhan investasi di daerah, yang selanjutnya dapat meningkatkan PAD dan kejahteraan masyarakat.

\section{Telaah Teori dan Pengembangan Hipotesis}

\subsection{Teori Agensi}

Teori keagenan mendeskripsikan hubungan antara pemegang saham sebagai 
prinsipal dan manajemen sebagai agen. Jensen dan Meckling (1976), menjelaskan hubungan keagenan merupakan suatu kontrak di mana satu orang atau lebih (prinsipal) memerintah orang lain (agen) untuk melakukan suatu jasa layanan atas nama prinsipal yang disertai dengan pendelegasian wewenang kepada agen dalam membuat keputusan yang terbaik bagi prinsipal. Jika kedua belah pihak tersebut mempunyai tujuan yang sama untuk memaksimumkan nilai perusahaan, maka diyakini agen akan bertindak dengan cara yang sesuai dengan kepentingan prinsipal. Prinsipal dapat membatasi perbedaan kepentingannya dengan memberikan insentif yang tepat kepada agen dengan melakukan pengawasan untuk membatasi penyimpangan kegiatan yang dilakukan oleh agen. Selain itu dalam beberapa situasi prinsipal dapat meminta agen untuk memberikan jaminan bahwa agen tidak akan mengambil tindakan-tindakan tertentu yang akan merugikan prinsipal atau untuk menjamin bahwa prinsipal akan diberi kompensasi jika agen tidak mengambil tindakan seperti yang disepakati. Pada umumnya tidak mungkin dengan tanpa biaya prinsipal dapat memastikan bahwa agen akan membuat keputusan yang optimal dari sudut pandang prinsipal. Dalam kebanyakan hubungan antara prinsipal dan agen akan timbul biaya monitoring (finansial atau non finansial), dan di samping itu akan ada beberapa perbedaan keputusan agen dalam memaksimalkan kesejahteraan prinsipal.

\subsection{Hubungan Keagenan antara Eksekutif dan Legislatif}

Dalam penyelenggaraan pemerintahan daerah terdapat hubungan keagenan antara legislatif dan eksekutif, dalam hal ini legislatif adalah sebagai prinsipal dan eksekutif adalah sebagai agen. Legislatif (DPRD) merupakan lembaga perwakilan rakyat daerah dan berkedudukan sebagai unsur penyelenggaraan pemerintahan daerah. DPRD memiliki fungsi legislasi, anggaran, dan pengawasan (UU nomor 32 Tahun 2004) sebagai berikut:

1. Fungsi legislasi, diwujudkan dalam membentuk Peraturan Daerah bersama Kepala Daerah;

2. Fungsi anggaran/budgeting, diwujudkan dalam menyusun dan menetapkan APBD bersama Pemerintah Daerah;

3. Fungsi pengawasan, diwujudkan dalam bentuk pengawasan terhadap pelaksanaan
Undang-undang, Peraturan Daerah, Keputusan Kepala Daerah dan kebijakan yang ditetapkan oleh Pemerintah Daerah.

DPRD juga memiliki tugas dan wewenang sebagai berikut:

1. Membentuk Peraturan Daerah yang dibahas dengan Kepala daerah untuk mencapai tujuan bersama;

2. Menetapkan Anggaran Pendapatan dan Belanja Daerah bersama dengan Kepala Daerah;

3. Melaksanakan pengawasan terhadap pelaksanaan Peraturan Daerah dan Peraturan Perundang-undangan, Keputusan Kepala Daerah, Anggaran Pendapatan dan Belanja Daerah, kebijakan Pemerintah Daerah dalam melaksanakan Program Pembangunan Daerah, dan Kerjasama Internasional di daerah;

4. Mengusulkan pengangkatan dan pemberhentian Kepala Daerah/Wakil Kepala Daerah kepada Menteri Dalam Negeri Republik Indonesia melalui Gubernur;

5. Memberikan pendapat dan pertimbangan kepada Pemerintah Daerah terhadap rencana perjanjian internasional yang menyangkut kepentingan daerah;

6. Meminta laporan pertanggungjawaban Kepala Daerah dalam pelaksanaan tugas desentralisasi.

Sementara itu eksekutif (Kepala

Daerah) mempunyai tugas dan wewenang:

1. Memimpin penyelenggaraan pemerintahan daerah berdasarkan kebijakan yang ditetapkan bersama DPRD;

2. Mengajukan rancangan Perda;

3. Menetapkan Perda yang telah mendapat persetujuan bersama DPRD;

4. Menyusun dan mengajukan rancangan Perda tentang APBD kepada DPRD untuk dibahas dan ditetapkan bersama;

5. Mengupayakan terlaksananya kewajiban daerah;

6. Mewakili daerahnya di dalam dan di luar pengadilan, dan dapat menunjuk kuasa hukum untuk mewakilinya sesuai dengan peraturan perundang-undangan; dan

7. Melaksanakan tugas dan wewenang lain sesuai dengan peraturan perundangundangan.

Hubungan keagenan timbul pada saat legislatif menjalankan fungsi legislasi dan fungsi penggangaran/budgeting. 
Dalam pembuatan kebijakan/peraturan perundangan, legistatur adalah prinsipal yang mendelegasikan kewenangan kepada eksekutif untuk merancang dan membuat kebijakan baru. Proses penyusunan APBD melibatkan eksekutif dan legislatif dengan berpedoman pada Arah dan Kebijakan Umum APBD dan prioritas anggaran. Pihak eksekutif membuat rancangan APBD yang kemudian diserahkan kepada legislatif untuk dipelajari dan dibahas bersamasama sebelum ditetapkan sebagai Peraturan Daerah (Perda). Dalam perspektif keagenan, APBD merupakan bentuk kontrak yang dijadikan alat oleh legislatif untuk mengawasi pelaksanaan anggaran oleh eksekutif (Halim dan Abdullah, 2006). Dalam peraturan tersebut dinyatakan semua kewajiban dan hak pihakpihak yang terlibat dalam pemerintahan. Eksekutif akan membuat pertanggungjawaban kepada legislatif setiap tahun atas anggaran yang dilaksanakannya dan setiap lima tahun ketika masa jabatan kepala daerah berakhir.

\subsection{Hubungan Keagenan antara Legislatif dan Publik}

Dalam hubungan keagenan antara legislatif dan publik, legislatif adalah agen dan publik adalah prinsipal. Menurut Von Hagen (dalam Halim dan Abdullah, 2006) bahwa hubungan prisipal dan agen yang terjadi antara publik dan legislatifpada dasarnya menunjukkan bagaimana publik memilih politisi untuk membuat keputusan-keputusan tentang belanja publik untuk mereka dan mereka memberikan dana dengan membayar pajak. Ketika legislatif kemudian terlibat dalam pembuatan keputusan atas pengalokasian belanja dalam anggaran, maka mereka diharapkan mewakili kepentingan pemilihnya. Jadi walaupun legislatif menjadi pihak prinsipal, di sisi lain dapat bertindak sebagai agen dalam hubungannya dengan publik. Sehingga legislatif menempatkan dirinya sebagai pihak yang menerima tugas dari publik, dan melakukan pendelegasian kepada eksekutif untuk menjalankan penganggaran.

\subsection{Penelitian Terdahulu}

Darwanto dan Yulia Yustikasari (2007), meneliti Pengaruh Pertumbuhan Ekonomi, Pendapatan Asli Daerah (PAD) dan Dana Alokasi Umum (DAU) terhadap Pengalokasian Anggaran Belanja Modal pada Pemerintah Kabupaten/Kota se Pulau Jawa. Sampel yang digunakan dalam penelitian yaitu kabupaten/ kota di Jawa-Bali, periode penelitian dari tahun 2004 - 2005. Hasil penelitiannya membuktikan bahwa PAD dan DAU berpengaruh positif dan signifikan terhadap pengalokasian anggaran belanja modal. Sedangkan pertumbuhan ekonomi tidak berpengaruh positif terhadap pengalokasian anggaran belanja modal.

Anggiat (2009), meneliti Pengaruh Pertumbuhan Ekonomi, Pendapatan Asli Daerah (PAD), Dana Alokasi Umum (DAU), dan Dana Alokasi Khusus (DAK) terhadap Anggaran Belanja Modal Pada Pemerintah Kabupaten/Kota se-Sumatera Utara. Hasil penelitiannya membuktikan bahwa secara simultan Pertumbuhan Ekonomi, Pendapatan Asli Daerah, Dana Alokasi Umum dan Dana Alokasi Khusus berpengaruh signifikan terhadap belanja modal di Kabupaten/Kota di Sumatera Utara. Secara parsial variabel Pendapatan Asli Daerah (PAD), Dana Alokasi Umum (DAU) dan Dana Alokasi Khusus (DAK) yang berpengaruh signifikan terhadap belanja modal di Kabupaten/Kota di Sumatera Utara, sedangkan Pertumbuhan Ekonomi yang diproksikan oleh PDRB harga berlaku, tidak berpengaruh secara signifikan terhadap besarnya Belanja Modal.

Safitri (2009), Pengaruh Pertumbuhan Ekonomi, PAD dan DAU, terhadap Pengalokasian Anggaran Belanja Modal Pada Pemerintah Kabupaten/Kota Sumatera Utara. Jumlah populasi dalam penelitian sebanyak 29 kabupaten/kota, dengan menggunakan purposive sampling diperoleh sampel penelitian sebanyak 11 kabupaten/kota, periode penelitian dari tahun 2004 - 2006. Hasil penelitiannya menunjukkan bahwa secara parsial Pendapatan Asli Daerah (PAD) yang mempunyai pengaruh signifikan positif terhadap Belanja Modal . Sedangkan Pertumbuhan Ekonomi dan Dana Alokasi Umum (DAU) tidak berpengaruh signifikan terhadap Belanja Modal. Secara simultan Perumbuhan Ekonomi, PAD dan DAU menpunyai pengaruh positif terhadap Belanja Modal.

\subsection{Rumusan Hipotesis}

PAD, DBH, DAU dan DAK merupakan komponen utama penerimaan pemerintah daerah yang dapat digunakan untuk peningkatan belanja modal. PAD adalah penerimaan daerah yang bersumber dari potensi daerah itu sendiri 
yang meliputi pajak daerah, retribusi daerah, bagian laba usaha milik daerah, dan lain-lain penerimaan asli daerah yang sah. PAD dapat digunakan untuk membiayai kegiatan rutin maupun kegiatan pembangunan (belanja modal). Semakin besar PAD dalam struktur pembiayaan daerah, semakin besar pula belanja modal. DBH merupakan salah satu komponen penerimaan daerah yang bersumber dari APBN, yang terdiri dari DBH Pajak dan DBH Bukan Pajak. Dengan demikian sebenarnya DBH juga merupakan potensi yang ada di kabupaten/ kota bersangkutan, yang dapat dikembangkan potensinya oleh pemerintah daerah sehingga dapat memperbesar penerimaan daerah. Dengan semakin besarnya penerimaan $\mathrm{DBH}$ semakin besar pula belanja modal. DAU merupakan salah satu komponen penerimaan daerah yang bersumber dari APBN. Pemberian DAU bertujuan untuk menciptakan pemerataan kemampuan keuangan antar daerah yang berdasarkan pertimbangan kebutuhan dan potensi daerah. DAU bersifat "Block Grant" yang berarti penggunannya diserahkan kepada daerah sesuai dengan prioritas dan kebutuhan daerah dalam rangka pelaksanaan otonomi daerah, khususnya untuk menutupi kekurangan gaji pengawai negeri sipil dan untuk belanja pembangunan/belanja modal untuk peningkatan pelayanan kepada masyarakat. DAK dimaksudkan untuk mendanai kegiatan khusus yang menjadi urusan daerah dan merupakan prioritas nasional, sesuai dengan fungsi yang merupakan perwujudan tugas kepemerintahan di bidang tertentu, khususnya dalam upaya pemenuhan kebutuhan sarana dan prasarana pelayanan dasar masyarakat. Dengan demikian, semakin besar penerimaan daerah yang bersumber dari PAD, DBH, DAU, dan DAK, maka secara simultan pengaruhnya semakin besar terhadap belanja modal. Adapun hipotesis alternatif yang diajukan dalam penelitian ini adalah:

HA1 : PAD secara parsial berpengaruh signifikan terhadap belanja modal.

HA2 : DBH secara parsial berpengaruh signifikan terhadap belanja modal.

HA3 : DAU secara parsial berpengaruh signifikan terhadap belanja modal.

HA4 : DAK secara parsial berpengaruh signifikan terhadap belanja modal.

HA5 : PAD, DBH, DAU, dan DAK secara simultan berpengaruh signifikan terhadap belanja modal.

\section{Metode Penelitian}

Dalam penelitian ini peneliti mengambil obyek penelitian pada 26 Pemerintah Kabupaten/Kota di Provinsi Jawa Barat. Penelitian ini dilakukan untuk menganalisis laporan keuangan Pemerintah Kabupaten/Kota khususnya terkait dengan faktor-faktor yang mempengaruhi belanja modal. Penelitian ini merupakan penelitian yang menguji teori-teori melalui pengukuran variabel-variabel penelitian secara kuantitatif dan melakukan analisis data dengan prosedur statistik. Tujuan penelitian ini untuk menguji hipotesis penelitian yang berkaitan dengan variabel yang diteliti yaitu pengaruh PAD, DBH, DAU dan DAK terhadap Belanja Modal. Hasil pengujian data digunakan sebagai dasar untuk menarik kesimpulan penelitian, mendukung atau menolak hipotesis yang dikembangkan dari telaah teoritis.

Populasi dalam penelitian ini adalah 26 Pemerintah Kabupaten/Kota di Provinsi Jawa Barat. Data yang diperoleh dari laporan keuangan periode tahun 2008 - 2012. Pemilihan sampel dilakukan secara purposive sampling, dengan kriteria tertentu sebagai berikut :

1. Laporan realisasi APBD kabupaten/kota di Provinsi Jawa Barat yang secara konsisten dari tahun 2008 - 2012 yang dipublikasikan oleh Direktorat Jenderal Perimbangan Keuangan Kementerian Kaungan melaui website www.djpk.depkeu.go.id;

2. Kabupaten/ kota di Provinsi Jawa Barat yang tidak mengalami pemekaran dan atau masih mempunyai kewajiban anggaran kepada daerah pemekaran selama periode tahun 2008 - 2012. Kriteria ini dibuat untuk menghidari distorsi dikarenakan kabupaten induk masih mempunyai kewajiban untuk menghibahkan sejumlah APBD selama tiga tahun anggaran untuk mempersiapkan pembentukan dan keberlangsungan pemerintahan di kabupaten pemekaran.

Metode pengumpulan data dilakukan dengan cara penelitian kepustakaan (dokumentasi) untuk mendapatkan landasan teori atau pemikiran, jurnal serta data-data penelitian terdahulu yang ada hubungan dengan masalah yang diteliti. Pengumpulan data sekunder bersumber dari laporan realisasi APBD Pemerintah Kabupaten/Kota di Jawa Barat periode tahun 2008 - 2012 yang diperoleh dari publikasi Direktorat Jenderal Perimbangan Keuangan dalam wibsite www. 
djpk.depkeu.go.id. Berdasarkan dua kriteria di atas, dari 26 daerah kabupaten/kota di Provinsi Jawa Barat yang memenuhi kriteria untuk ditetapkan sebagai sampel penelitian sebanyak 24 kabupaten/kota.

Definisi Operasionalisasi Variabel yang digunakan dalam penelitian adalah sebagai berikut.

1. PAD adalah adalah penerimaan yang diperoleh daerah dari sumber-sumber dalam wilayahnya sendiri yang dipungut berdasarkan dengan peraturan perundangundangan yang berlaku. Pendapatan Asli Daerah (PAD) diukur dari total penerimaan pajak daerah, retribusi daerah, hasil kekayaan daerah yang dipisahkan, dan lainlain pendapatan asli daerah yang sah.

2. DBH adalah adalah dana yang bersumber dari pendapatan APBN yang dialokasikan kepada Daerah berdasarkan angka persentase untuk mendanai kebutuhan Daerah dalam rangka pelaksanaan Desentralisasi. DBH diukur dari total penerimaan DBH yang bersumber dari pajak dan Bukan Pajak (sumber daya alam). DBH Pajak terdiri dari bagi hasil Pajak Bumi dan Bangunan, Bea Perolehan Hak atas Tanah dan Bangunan, Pajak Penghasilan Pasal 25 dan Pasal 29 Wajib Pajak Orang Pribadi Dalam Negeri, dan Pajak Penghasilan Pasal 21. DBH sumber daya alam terdiri dari bagi hasil sumber daya alam kehutanan, pertambangan umum, perikanan, pertambangan minyak bumi, pertambangan gas bumi, dan pertambangan panas bumi.

3. DAU adalah dana yang bersumber dari pendapatan APBN yang dialokasikan dengan tujuan pemerataan kemampuan keuangan antar-daerah untuk mendanai kebutuhan daerah dalam rangka pelaksanaan Desentralisasi. DAU diukur dari total penerimaan transfer yang didasarkan pada Alokasi Dasar dan Celah Fiskal.

4. DAK adalah dana yang bersumber dari pendapatan APBN yang dialokasikan kepada Daerah tertentu dengan tujuan untuk membantu mendanai kegiatan khusus yang merupakan urusan Daerah dan sesuai dengan prioritas nasional. DAK diukur dari jumlah penerimaan DAK yang diberikan oleh pemerintah pusat.

5. Belanja modal adalah Belanja modal adalah pengeluaran anggaran untuk perolehan aset tetap dan aset lainnya yang memberi manfaat lebih dari satu periode akuntansi. Belanja modal meliputi antara lain belanja modal untuk perolehan tanah, gedung dan bangunan, peralatan, aset tak berwujud. Belanja diukur dari total realisasi belanja modal pemerintah kabupaten/kota

Alat analisis yang digunakan untuk melihat pengaruh PAD, DBH, DAU, dan DAK terhadap belanja modal dalam penelitian ini adalah analisis regresi linier berganda. Uji asumsi klasik dilakukan untuk memenuhi persyaratan statistik pada analisis regresi linear berganda yang berbasis ordinary least square (OLS). Uji asumsi klasik yang digunakan yaitu uji multikolinieritas, uji autokorelasi, uji heteroskedastisitas, dan uji normalitas.

\section{Hasil Penelitian dan Pembahasan}

Sebagaimana diuraikan pada bagian sebelumnya bahwa dari sebanyak 26 kabupaten/ kota, yang memenuhi dan ditetapkan sebagai obyek dalam penelitian ini adalah 24 kabupaten/ kota. Statistik deskriptif dari variabel tersebut selama periode tahun 2008 - 2012 adalah sebagai berikut:

Tabel 1

Deskripsi data penelitian

\begin{tabular}{llllll}
\hline & $\mathbf{N}$ & \multicolumn{1}{c}{ Minimum } & \multicolumn{1}{c}{ Maksimum } & \multicolumn{1}{c}{ Rata-rata } & Rata-rata Nasional \\
\hline PAD & 120 & 23.782 .320 .837 & 1.048 .230 .000 .000 & 180.108 .030 .195 & 62.098 .855 .998 \\
DBH & 120 & 34.347 .686 .905 & 52.652 .0943 .045 & 149.758 .423 .630 & 129.924 .438 .580 \\
DAU & 120 & 191.153 .331 .000 & 1.672 .610 .000 .000 & 715.732 .563 .829 & 399.493 .595 .262 \\
DAK & 120 & 4.570 .515 .000 & 159.725 .600 .000 & 591.99 .409 .506 & 47.162 .902 .375 \\
BM & 120 & 56.290 .977 .928 & 1.035 .470 .000 .000 & 228.034 .506 .089 & 169.711 .144 .462 \\
Valid N & 120 & & & & \\
(listwise) & & & & & \\
\hline
\end{tabular}


Berdasarkan tabel 3, dapat dijelaskan bahwa jumlah data $(\mathrm{N})$ sebanyak 120 selama periode 2008 - 2012, dan maka karakteristik data untuk masing-masing variabel dapat dijelaskan sebagai berikut:

1. Nilai minimum data PAD adalah 23.782.320.837,- nilai maksimum adalah 1.048.230.000.000,- dan nilai rata-rata PAD adalah 180.108.030.195,- Jika dibandingkan dengan rata-rata PAD Kabupaten/Kota di seluruh Indonesia yaitu sebesar 62.098.855.998,- maka rata-rata PAD Kabupaten/Kota di Provinsi Jawa Barat lebih besar dari rata-rata nasional. Dari data penelitian juga diperoleh informasi bahwa rata-rata kontribusi PAD terhadap total pendapatan daerah kabupaten/kota di Provinsi Jawa Barat sebesar 13 persen, lebih tinggi dari rata-rata nasional yaitu sebesar 8 persen.

2. Nilai minimum data dana bagi hasil (DBH) adalah 34.347.686.905,-, nilai maksimum adalah 526.520.943.045,- dan nilai rata-rata adalah 149.758.423.630,-Jika dibandingkan dengan rata-rata $\mathrm{DBH}$ Kabupaten/Kota di seluruh Indonesia yaitu sebesar 129.924.438.580,- maka rata-rata DBH Kabupaten/Kota di Provinsi Jawa Barat lebih besar dari rata-rata nasional. Dari data penelitian juga diperoleh informasi bahwa rata-rata kontribusi DBH terhadap total pendapatan daerah kabupaten/kota di Provinsi Jawa Barat sebesar 11 persen, lebih rendah dari rata-rata nasional yaitu sebesar 18 persen.

3. Nilai minimum data DAU adalah 191.153.331.000,-, nilai maksimum adalah 1.672.610.000.000,- dan nilai rata-ratanya adalah 715.732.563.829,-. Jika dibandingkan dengan rata-rata DAU Kabupaten/Kota di seluruh Indonesia yaitu sebesar 399.493.595.262,- maka rata-rata DAU Kabupaten/Kota di Provinsi Jawa Barat lebih besar dari rata-rata nasional. Dari data penelitian juga diperoleh informasi bahwa rata-rata kontribusi DAU terhadap total pendapatan daerah kabupaten/kota di Provinsi Jawa Barat sebesar 51 persen, sedikit lebih rendah dari rata-rata nasional yaitu sebesar 54 persen. Tinggi kontribusi DAU terhadap penerimaan daerah mencerminkan ketergantungan yang tinggi terhadap Pemerintah Pusat.

4. Nilai minimum data DAK adalah
4.570.515.000,-, nilai maksimum adalah 159.725.600.000,- dan nilai rata-ratanya adalah 59.199.409.506,-. Jika dibandingkan dengan rata-rata DAK Kabupaten/ Kota di seluruh Indonesia yaitu sebesar 47.162.902.375,- maka rata-rata DAK Kabupaten/Kota di Provinsi Jawa Barat sedikit di atas rata-rata nasional. Dari data penelitian juga diperoleh informasi bahwa rata-rata kontribusi DAK terhadap total pendapatan daerah kabupaten/kota di Provinsi Jawa Barat hanya sebesar 4 persen, sedikit lebih rendah dari rata-rata nasional yaitu sebesar 6 persen.

5. Nilai minimum data belanja modal adalah 56.290.977.928,-, nilai maksimum adalah 1.035.470.000.000,- dan nilai rata-ratanya adalah 228.034.506.089,-. Jika dibandingkan dengan rata-rata belanja modal Kabupaten/Kota di seluruh Indonesia yaitu sebesar 169.711.144.462,maka rata-rata belanja modal Kabupaten/ Kota di Provinsi Jawa Barat di atas ratarata nasional. Dari data penelitian juga diperoleh informasi bahwa proporsi ratarata belanja modal terhadap total belanja daerah kabupaten/kota di Provinsi Jawa Barat sebesar 17 persen, lebih rendah dari rata-rata nasional yaitu sebesar 24 persen. Data ini menunjukkan bahwa belanja modal Pemerintah Kabupaten/Kota di Provinsi Jawa Barat masih rendah, dan masih di bawah amanah PP Nomor 55 Tahun 2010 tentang RPJM Nasional Tahun Anggaran 2010 - 2014 bahwa belanja modal Pemerintah daerah minimal 29\% dari belanja daerah.

Pengujian hipotesis bertujuan untuk mendapatkan kesimpulan apakah hipotesis penelitian yang telah dirumuskan didukung atau tidak didukung oleh data empirik yang telah dikumpulkan. Adapun hasil pengujian pengaruh PAD, DBH, DAU dan DAK terhadap belanja modal adalah sebagai berikut :

1. Nilai Adjusted $\mathrm{R}^{2}$ sebesar 0,721. Angka tersebut menunjukkan bahwa bahwa 72,1\% variasi variabel Belanja Modal dapat dijelaskan oleh variabel PAD, DBH, DAU, dan DAK, sedangkan sisanya sebesar $27,9 \%$ dijelaskan oleh variable lain yang tidak dijelaskan dalam model penelitian ini.

2. Uji statistik $t$ variabel PAD memiliki $t$ hitung sebesar 4.303 lebih besar dari t tabel sebesar $2.450(\alpha=5 \%)$, dengan nilai 
signifikansi sebesar 0.000 atau lebih kecil dari $0.05(\alpha=5 \%)$, sehingga hipotesis alternatif dua (HA1) diterima dan menolak hipotesis nol (Ho). Ini berarti bahwa PAD berpengaruh signifikan positif terhadap belanja modal.

3. Uji statistik t variabel Dana Bagi Hasil (DBH) memiliki t hitung sebesar 4.357 lebih besar dari t tabel sebesar $2.450(\alpha=5$ $\%)$, dengan nilai signifikansi sebesar 0.000 atau lebih kecil dari $0.05(\alpha=5 \%)$, sehingga hipotesis alternatif tiga (HA2) diterima dan menolak hipotesis nol (Ho). Ini berarti bahwa DBH berpengaruh signifikan positif terhadap belanja modal.

4. Uji statistik $\mathrm{t}$ variabel $\mathrm{DAU}$ memiliki $\mathrm{t}$ hitung sebesar 3.488 lebih besar dari t tabel sebesar $2.450(\alpha=5 \%)$, dengan nilai signifikansi sebesar 0.001 atau lebih kecil dari $0.05(\alpha=5 \%)$, sehingga hipotesis alternatif empat (HA3) diterima dan menolak hipotesis nol (Ho). Ini berarti bahwa DAU berpengaruh signifikan positif terhadap belanja modal.

5. Uji statistik $\mathrm{t}$ variabel $\mathrm{DAK}$ memiliki $\mathrm{t}$ hitung sebesar 0.411 lebih kecil dari $\mathrm{t}$ tabel sebesar $2.450(\alpha=5 \%)$, dengan nilai signifikansi sebesar 0.682 atau lebih besar dari $0.05(\alpha=5 \%)$, sehingga hipotesis alternatif lima (HA4) ditolak dan menerima hipotesis nol (Ho). Ini berarti bahwa DAK tidak berpengaruh signifikan terhadap belanja modal.

6. Hasil uji statistik $F$ diperorelh nilai $F$ hitung sebesar 77,841 lebih besar dari nilai $F$ tabel sebesar 2,45 dengan nilai signifikansi sebesar 0,000 atau lebih kecil dari $0.05(\alpha=$ $5 \%$ ). Ini berarti bahwa PAD, DBH, DAU, dan DAK secara simultan berpengaruh signifikan terhadap belanja modal (HA5).

Dari model persamaan regresi yang dihasilkan dalam penelitian ini, terlihat bahwa belanja modal di kabupaten/kota di Provinsi Jawa Barat secara signifikan dipengaruhi oleh PAD. Hasil penelitian ini sejalan dengan penelitian yang dilakukan oleh Daryanto dan Yulia Yustikasari (2007), Anggiat Situngkir (2009), Irma Safitri (2009), dan Vicky Nur Rachma (2011). PAD merupakan pendapatan yang berasal dari potensi daerah sehingga daerah dapat dengan leluasa menggunakan PAD untuk membiayai kegiatan rutin maupun belanja modal/belanja pembangunan. Namun demikian kontribusi PAD terhadap total pendapatan kabupaten/kota di Provinsi Jawa Barat masih relatif kecil yaitu sebesar 13 persen. Pemerintah daerah perlu berupaya lebih keras untuk meningkatkan penerimaan PAD agar penerimaannya mendekati atau bahkan sama dengan potensinya. Menurut Widayat (1994), upaya peningkatan PAD dapat dilakukan dengan cara instensifikasi dan ekstensifikasi. Cara instensifikasi adalah mengefektifkan pemungutan pajak atau retribusi dan mengefisienkan cara pemungutannya pada obyek dan subyek yang sudah ada misalnya melakukan perhitungan potensi, penyuluhan, meningkatkan pengawasan dan pelayanan. Cara ekstensifikasi adalah melakukan usahausaha untuk meningkatkan PAD dengan cara menjaring wajib pajak baru melalui pendataan dan pendaftaran atau menggali pajak baru. Selain itu, Pemerintah Daerah juga perlu untuk meningkatkan daya saing daerah. Isu strategis terkait dengan peningkatan daya saing meliputi: (1) peningkatan iklim investasi dan usaha; (2) percepatan pembangunan infrastruktur untuk keterhubungan dalam negeri; (3) peningkatan pembangunan industri di berbagai koridor ekonomi; dan (4) penciptaan kesempatan kerja, khususnya tenaga kerja muda (RKP T.A. 2013).

Dana Bagi Hasil merupakan salah satu komponen penerimaan daerah yang bersumber dari APBN, yang terdiri dari DBH Pajak dan DBH Bukan Pajak (sumber daya alam). Obyek DBH berada pada kabupaten/kota bersangkutan. Dengan demikian sebenarnya DBH juga merupakan potensi yang ada di kabupaten dan kota bersangkutan, yang dapat dikembangkan potensinya oleh pemerintah daerah sehingga dapat memperbesar penerimaan daerah. Hasil penelitian ini menyatakan bahwa Dana Bagi Hasil berpengaruh signifikan terhadap belanja modal. Namun demikian, rata-rata kontribusi DBH terhadap total pendapatan daerah kabupaten/kota di Provinsi Jawa Barat hanya sebesar 11 persen, lebih rendah dari rata-rata nasional yaitu sebesar 18 persen. Adapun sumber utama penerimaan utama DBH Kabupaten/Kota di Provinsi Jawa Barat berasal dari DBH Pajak yang besarnya mencapai 81 persen, sedangkan penerimaan yang berasal dari dana bagi hasil sumber daya alam hanya mencapai 19 persen.

Potensi penerimaan DBH yang bisa dikembangkan oleh Pemerintah Kabupaten/ Kota di Provinsi Jawa Barat adalah DBH Pajak yang berasal dari penerimaan Pajak 
Bumi dan Bangunan (PBB), Bea Perolehan Hak atas Tanah dan Bangunan (BHTB), Pajak Penghasilan Pasal 25 dan Pasal 29 Wajib Pajak Orang Pribadi Dalam Negeri, dan Pajak Penghasilan Pasal 21. Selain itu, beberapa pajak yang masih dikelola oleh pusat sudah saatnya untuk diserahkan kepada daerah. Langkah langkah yang perlu dilakukan dalam meningkatkan penerimaan bagi hasil sektor perpajakan yaitu meningkatkan Sumber Daya Manusia aparat pemungut pajak, efisiensi biaya pemungutan pajak, meningkatkan pengawasan, penyuluhan kepada wajib pajak, meingkatkan pelayanan dan kemudahan pembayaran pajak, dan pemutakhiran data wajib pajak.

Hasil penelitian ini juga menunjukkan bahwa DAU berpengaruh secara positif dan signifikan terhadap belanja modal. Elastisitas belanja modal terhadap DAU adalah sebesar 0,415 yang berarti bahwa setiap kenaikan DAU sebesar $1 \%$, maka belanja modal akan meningkat sebesar $0,415 \%$ cateris paribus. Hasil penelitian ini mendukung hasil penelitian yang dilakukan oleh Daryanto dan Yulia Yustikasari (2007), Anggiat Situngkir (2009) yaitu bahwa DAU berpengaruh signifikan positif terhadap belanja Modal.

Rata-rata kontribusi DAU terhadap total pendapatan daerah kabupaten/kota di Provinsi Jawa Barat sebesar 51 persen, sedikit lebih rendah dari rata-rata nasional yaitu sebesar 54 persen. Tingginya kontribusi DAU terhadap penerimaan daerah mencerminkan adanya ketergantungan yang tinggi terhadap Pemerintah Pusat. Terjadi transfer dana yang cukup signifikan di dalam APBN dari pemerintah pusat ke pemerintah daerah, perlu dibarengi adanya penyerahan kewenangan, sehingga pemerintah daerah secara leluasa dapat menggunakan dana ini apakah untuk memberi pelayanan yang lebih baik kepada masyarakat atau untuk keperluan lain yang tidak penting.

Berdasarkan pengujian pengaruh dana alokasi khusus terhadap belanja modal menunjukkan bahwa DAK berpengaruh secara positif namun secara statistik tidak signifikan terhadap belanja modal. Walaupun tidak signifikan, tanda positif koefisien variabel DAK menunjukkan bahwa instrumen DAK telah sejalan dengan tujuan pengalokasian DAK, yaitu untuk mendanai kepentingan khusus yang merupakan urusan Pemerintahan Daerah dan sesuai dengan prioritas nasional, khususnya untuk membiayai kebutuhan sarana dan prasarana pelayanan dasar masyarakat yang belum mencapai standar tertentu atau untuk mendorong percepatan pembangunan daerah. Tidak signifikannya variabel DAK dapat dijelaskan karena rata-rata kontribusi DAK terhadap total pendapatan daerah kabupaten/kota di Provinsi Jawa Barat sangat kecil yaitu hanya sebesar 4 persen, lebih rendah dari rata-rata nasional yaitu sebesar 6 persen. Selain itu, Pemerintah daerah tidak leluasa dalam mengelola DAK karena kebijakan pengalokasian DAK sepenuhnya ditentukan oleh Pemeringah Pusat, dengan beberapa kriteria, yaitu Kriteria Teknis yang ditentukan oleh Departemen Teknis dengan mempertimbangkan luas wilayah, panjang jalan dan sebagainya. Kriteria Khusus untuk daerah khusus, misalnya daerah bencana alam, pesisir atau pariwisata. Kriteria Fiskal yang ditentukan Departemen Keuangan.

Implikasi dari hasil penelitian ini menunjukkan bahwa pengeluaran belanja modal Pemerintah Kabupaten/Kota di Provinsi Jawa Barat sangat dipengaruhi oleh sumber-sumber penerimaan utama baik yang merupakan Pendapatan Asli Daerah itu sendiri maupun dana tranfer dari Pemerintah Pusat dalam bentuk Dana Bagi Hasil, Dana Alokasi Umum, dan Dana Alokasi Khusus. Hal ini didukung masih tingginya ketergantungan fiskal Pemerintah Kabupaten/Kota di Provinsi Jawa Barat kepada Pemerintah Pusat yang dicerimkan oleh besarnya kontribusi dana tranfer dari Pemerintah Pusat selama periode penelitian. Dengan struktur anggaran yang masih bergantung pada pemerintah pusat maka perubahan kebijakan dana transfer akan berimplikasi terhadap belanja modal pemerintah daerah. Penurunan penerimaan dana transfer akan berakibat menurunnya belanja modal/belanja infrastruktur publik yang sangat diperlukan oleh masyarakat maupun dunia usaha seperti infrastruktur transportasi, komunikasi, pendidikan, kesehatan, ekonomi, olah raga dan kesenian dan lain-lain.

Dari tabel 5 dapat dianalis bahwa kontribusi PAD kabupaten/kota di Provinsi Jawa Barat rata-rata hanya 10 persen terhadap total penerimaan daerah selama kurun waktu 2008 - 2012, sementara komponen dana tranfer dari Pemerintah Pusat yang tediri dari DBH, DAU dan DAK mempunyai kontribusi sebesar 64 persen. 
Tabel 2

Rata-rata komposisi penerimaan Kabupaten/Kota

Di Provinsi Jawa Barat T.A. 2008 - 2012

\begin{tabular}{|c|c|c|c|c|c|c|}
\hline $\begin{array}{c}\text { Penerimaan } \\
\text { Daerah }\end{array}$ & 2008 & 2009 & 2010 & 2011 & 2012 & Rerata \\
\hline PAD & $9 \%$ & $9 \%$ & $10 \%$ & $7 \%$ & $13 \%$ & $10 \%$ \\
\hline DBH & $11 \%$ & $12 \%$ & $11 \%$ & $9 \%$ & $8 \%$ & $10 \%$ \\
\hline DAU & $55 \%$ & $51 \%$ & $47 \%$ & $47 \%$ & $54 \%$ & $50 \%$ \\
\hline DAK & $3 \%$ & $4 \%$ & $4 \%$ & $4 \%$ & $4 \%$ & $4 \%$ \\
\hline Lain-lain & $11 \%$ & $15 \%$ & $17 \%$ & $26 \%$ & $14 \%$ & $17 \%$ \\
\hline Pembiayaan & $11 \%$ & $10 \%$ & $11 \%$ & $8 \%$ & $8 \%$ & $9 \%$ \\
\hline Total & $100 \%$ & $100 \%$ & $100 \%$ & $100 \%$ & $100 \%$ & $100 \%$ \\
\hline
\end{tabular}

Kondisi ketergantungan fiskal kepada Pemerintah Pusat menjadikan daerah tidak leluasa mengelola anggarannya dalam memberikan pelayanan kepada publik. Oleh karena itu, Pemerintah daerah harus merancang dan menetapkan berbagai skema peningkatan PAD dengan berbagai cara antara lain: (1) Intensifikasi dan ekstensifikasi pungutan daerah dalam bentuk pajak atau retribusi, (2) Eksplorasi sumber daya alam, dan (3) Skema pembentukan capital (capital formation) atau investasi daerah melalui penggalangan dana atau menarik investor. Selain itu, pemerintah daerah harus melakukan upaya-upaya efisiensi dan efektivitas anggaran melalui perencanaan yang partispatif, sehingga program kerja yang dilaksanakan sesuai dengan kebutuhan masyarakat.

\section{Simpulan, Keterbatasan, Implikasi Hasil Penelitian}

Berdasarkan hasil penelitian diatas maka dapat disimpulkan sebagai berikut :

1. Secara parsial Pendapatan Asli Daerah, Dana Bagi Hasil, Dana Alokasi Umum berpengaruh signifikan terhadap belanja modal Pemerintah Kabupaten/Kota di Provinsi Jawa Barat. Hasil ini konsisten dengan hasil penelitian yang dilakukan oleh Darwanto dan Yustikasari (2007), Situngkir (2009), Safitri (2009), dan Anwar Saroji (2010).

2. Secara parsial Dana Alokasi Khusus tidak berpengaruh signifikan terhadap belanja modal Pemerintah Kabupaten/Kota di Provinsi Jawa Barat. Tidak signifikannya variabel DAK dapat dijelaskan karena rata-rata kontribusi DAK terhadap total pendapatan daerah kabupaten/kota di Provinsi Jawa Barat sangat kecil yaitu hanya sebesar 4 persen, lebih rendah dari rata-rata nasional yaitu sebesar 6 persen.

3. Secara simultan Pendapatan Asli Daerah, Dana Bagi Hasil, dana Alokasi Umum dan Dana Alokasi Khusus berpengaruh signifikan terhadap belanja modal Pemerintah Kabupaten/ Kota di Provinsi Jawa Barat.

Adapun keterbatasan dalam penelitian ini yaitu obyek penelitian ini dibatasi pada kabupaten/kota tertentu yang memenuhi kriteria yang telah ditetapkan, yaitu 24 kabupaten/kota, sehingga hasilnya belum dapat digeneralisasi untuk seluruh kabupaten/kota di Indonesia. Selain itu, rentang waktu data yang digunakan dalam penelitian ini hanya 5 tahun, akan lebih baik jika data yang digunakan adalah data yang mempunyai rentang waktu lebih lama. Maka saran yang dapat diberikan untuk penelitian berikutnya adalah :

1. Bagi peneliti selanjutnya agar dapat memperluas atau menambah sampel penelitian seperti seluruh daerah kabupaten/kota di pulau jawa atau seluruh Indonesia atau dengan menambah periode pengamatan.

2. Peneliti berikutnya sebaiknya menambah variabel lain atau faktor-faktor lain yang 
mempengaruhi belanja modal seperti pertumbuhan ekonomi, kapasitas fiskal daerah, inflasi, Indek Pembangunan Manusia (IPM), Dana Tugas Pembantuan, Hibah, dan lain lain.

3. Pemerintah Kabupaten/Kota di Provinsi Jawa Barat sebaiknya menggali PAD yang dimilikinya lebih maksimal, dengan cara menambah jenis pajak baru serta pungutan lainnya yang diimbangi dengan peningkatan pelayanan publik serta perbaikan sistem pengelolaan dan juga pengawasan, pengembangan potensi pariwisata, dan lain-lain.

4. Mengingat terbatasnya kemampuan keuangan Pemerintah Daerah, maka kerjasama pemerintah daerah dan swasta dalam pembangunan infrastruktur perlu didorong.

\section{Daftar Pustaka}

Arifintar, M. (2013). Pengaruh Pendapatan Asli Daerah, Dana Bagi Hasil Pajak, Dana Alokasi Umum, Dana Alokasi Khusus, Jumlah Tenaga Kerja Dan Belanja Modal Terhadap Pertumbuhan Ekonomi Di Solo Raya Tahun 2004-2011 (Doctoral dissertation, Universitas Sebelas Maret)

Darwanto dan Yustikasari, Yulia. 2007. Pengaruh Pertumbuhan Ekonomi, Pendapatan Asli Daerah dan Dana Alokasi Umum terhadap Pengalokasian Anggaran Belanja Modal. BPFE UGM. Jurnal Akuntansi dan Keuangan Sektor Publik, Vol. 08. No. 01..

Direktorat Jenderal Perimbangan Keuangan, Kementerian Keuangan. www.djpk.depkeu. go.id

Halim, Abdul \& Syukri Abdullah. 2006. Hubungan dan Masalah Keagenan di Pemerintahan Daerah: Sebuah Peluang Penelitian Anggaran dan Akuntansi. Jurnal Akuntansi Pemerintah 2 (1): 53-64.

Jensen, Michel C., Willian H. Meckling. 1976. Theory of Firm: Managerial Beahvior, Agency Cost and Ownership Structure, The Journal of Financial Economics, October 1976.

Kinseng, Rilus A. 2001. Bahaya Kesenjangan Pembangunan Antar Wilayah: Suatu Tinjauan Sosiologis. Civis, Vol. 3 No. 2..

Rahma, Vicky Nur. 2011. Pengaruh Pajak Daerah, Retribusi Daerah, dan Lain-lain
Pendapatan Asli Daerah (PAD) yang sah terhadap Belanja Modal. Tesis S-2, Universitas Pancasila, Jakarta (Tidak diplubikasikan).

Safitri, Irma. 2009. Pengaruh Pertumbuhan Ekonomi, PAD dan DAU, terhadap Pengalokasian Anggaran Belanja Modal Pada Pemerintah Kabupaten/Kota Sumatera Utara. Skripsi S-1, Universitas Sumatera Utara, Medan (Tidak diplubikasikan).

Sidik, Machfud, Raksaka Mahi, Robert Simanjuntak dan Bambang Brodjonegoro. 2002. Dana Alokasi Umum: Konsep, Hambatan dan Prospek di Era Otonomi Daerah. Jakarta: Buku Kompas.

Situngkir, Anggiat. 2009. Pengaruh Pertumbuhan Ekonomi, Pendapatan Asli Daerah, Dana Alokasi Umum Dan Dana Alokasi Khusus Terhadap Anggaran Belanja Modal Pada Pemkot/Pemkab Sumatera Utara. Tesis S-2, Universitas Sumatera Utara, Medan (Tidak diplubikasikan).

Widayat, Wahyu. 1994. Maksimalisasi Pendapatan Asli Daerah sebagai Kekuatan Ekonomi Daerah, Jurnal Akuntansi dan Manajemen, STIE YKPN, XXI/No.3, 28-34. Republik Indonesia. 2004. Undang-Undang Nomor 32 Tahun 2004 tentang Pemerintah Daerah. Lembaran Negara Republik Indonesia Tahun 2004 Nomor 125, Tambahan Lembaran Negara Republik Indonesia Nomor 4437.

Direktorat Jenderal Perimbangan Keuangan, Kementerian Keuangan. www.djpk.depkeu. go.id

Adi, A. (2013). Pengaruh Return On Equity, Debt To Equity Ratio, Earning Per Share Dan Book Value Per Share Terhadap Harga Saham (Studi pada Perusahaan Consumer Goods Industry yang Terdaftar di BEI Periode Tahun 2008-2011). Jurnal Administrasi Bisnis, 4(2). 